УДК 665.254.22

( I. Л. Побідаш, к.філол.н., доцент, КП। ім. Ігоря Сікорського, Київ, Україна

\title{
АВТОРСЬКА РЕДАКЦІЯ
}

\section{Здійснено спробу виокремити й охарактеризувати основне} коло проблемних питань, пов'язаних з авторським редагуванням. Узагальнено позитивний та негативний досвід побутування друкованих матеріалів в авторській редакції.

Ключові слова: завдання редактора; авторське редагування; якість публікацій; редакційно-видавничий процес; саморедагування; авторське редагування; літературний редактор; редакційна етика.

\section{Постановка проблеми}

Редактор і автор - два суб'єкта діяльності, у якихє коло обов'язків і прав. Твір як продукт діяльності належить авторові. Ім'я ж редактора залишається «за лаштунками», хоча важко переоцінити його значний обсяг роботи. Взаємини редактора з автором багатоаспектний, цілісний процес від задуму до виходу друкованого продукту. Зважаючи на те, що рівень автора може бути різним (від початківця до знаменитого й уславленого преміями), основою і дороговказом є саме редактор, який учить, допомагає, спрямовує, підтримує, вміє, знає, може. Функції редактора зазнають змін щодо сучасних вимог життя і виробництва, однак серцевина цих функцій незмінна: оцінювання рукопису; доведення рукопису до відповідного рівня в літературному і науковому сенсі; робота над апаратом видання, художнім оформленням; технічна розмітка рукопису; коректорська робота над рукописом; звірка і вичитка рукопису; прийняття рішення про випуск видання в світ [17, С. 159-161]. Під час редакторськовидавничого процесу редактор $\epsilon$ керівником. Саме він $€$ основою вдалого (вибір авторів, укладання грамотно договору, приймання оригіналу тощо) й якісного (структурний, інформативний, мовностильовий рівні) проекту видання. Звичайно, редактор повинен пам'ятати, що погодження правок із автором $є$ обов'язковим. Останне не так вже й просто. «Ви нівелюєте мене як автора», «Ви не розумієте», «Нехай буде в авторській редакції»... такі вислови знані в редакційних кабінетах.

\section{Мета роботи}

Окреслити проблемне коло питань, пов'язаного з існуванням на сучасному видавничому ринку продукту в авторській редакції. Визначити позитивні та негативні наслідки авторської редакції; провести опитування

(c) $2017 \mathrm{p}$. 
серед студентів-редакторів як майбутніх фахівців щодо питання правомірності авторської редакції; привернути увагу науковців до питання авторської редакції у сучасному книговиданні.

\section{Результати проведених досліджень}

Кваліфікована робота автора над твором $€$ не менш унікальним явищем, ніж професійна діяльність редактора. Чи не вперше спробував заповнити цю лакуну, поставивши кардинальне питання необхідності вивчення проблем і особливостей цієї специфічної діяльності, В. Галич, досліджуючи творчість О. Гончара як журналіста, публіциста, редактора [2, С. 798]. Вакуум, який утворився навколо питання авторського редагування, поступово заповнювався науковими дослідженнями В. Галич, Н. Зелінської, Р. Іванченка, О. Куцевської, 3. Партика, В. Різуна, М. Тимошика та інших.

«Становлення авторського редагування пройшло довгий шлях в історії української культури. Із часів літописання Київської Русі аж до наших днів воно розвивається як невід'ємна частина роботи автора над твором» [1, C. 23]. Саморедагування цілеспрямований мовленневокомунікативний процес, з індивідуальним почерком і творчим характером. В. Різун, вважає, що назвати саморедагування виправленням автором власних помилок - означає порушити основний закон загального редагування, адже таким чином ми нівелюємо письменницький потенціал і прагматику його творів, забуваючи, що редагування - це «проникнення у творчу лабораторію автора, щоб зрозуміти, що хотів сказати письменник, яким був його задум, 3 якою метою написав він текст» [1, C. 18]. Н. Лавриненко зазначає, що автор, виражаючи свій задум, спершу створює структурно не оформлений текст «для себе». Цей текст не обов'язково повинен мати закінчену смислову і знакову форму. «Перехід від мови «для себе» до «мови для інших» забезпечує сукупність дій з упорядкування пізнавального процесу відповідно до певних норм і правил мовного вираження. Завдання створити з тексту «для себе» текст «для інших» передбачає, що авторське бачення матеріалу, який викладається, має бути повністю оформлене в прийнятих у соціумі мовних одиницях і розташоване в лінійній послідовності [4, C. 180-181].

Тенденція сучасності - надання авторові можливості власноруч шліфувати свій текст, якість твору ще до подання у редакцію, максимально опрацьовуючи його, звертаючись або ні приватно до редакторів, філологів та ін.; подальше ж удосконалення (якщо воно потрібне), за порадою редактора, здійснює сам автор. Усе частіше читаємо ми у книгах або часописах «в авторській редакції»: Будьте ласкаві, стежте за належним граматичним і стилістичним оформленням ваших статей, адже вони публікуються в авторській редакції; Текст має бути уважно вичитаний і перевірений. Статті друкуються в авторській редакції. Відповідальність за допущені помилки несуть автори публікацій; Доповіді 
подаються в остаточній авторській редакції. Організатори не несуть відповідальності за інформацію, що публікується; Усі матеріали подані в авторській редакції, за науковий зміст яких, правильність використання літературних джерел відповідальність несе автор статті; Видано в авторській редакції. Погляди, викладені у цій роботі, належать авторам і не можуть тлумачитись як офіційна позиція Інституту... [3] тощо.

Це зручно для видавництва, але чи ефективно це з точки зору якості тексту?

Відсутність редакторського опрацювання тексту призводить до низького рівня видання. (Наприклад, відкривши на здогад три статті (22 сторінки), подані в авторській редакції, одного $з$ наукових збірників КПІ ім. Ігоря Сікорського (з етичних міркувань не зазначатимемо назву часопису), ми виявили 70 різнорідних помилок).

За умов авторської редакції роль редактора (спираючись на характер матеріалу, він проектує книжку, починаючи з функціонально-цільового комплексу [5] і закінчуючи стилістичними, мовними й технічними засобами забезпечення функцій книги) під час видання книги редукується. У нашому білінгвістичному просторі редагування просто необхідно.

Нині, зазначає в одному з інтерв'ю Н. Зелінська, книжки виходять некваліфіковано редаговані. Деякі ... видавці взагалі викреслюють редактора як ланку видавничого процесу [6]. Часто видання без редагування рукопису зумовлено такими причинами: 1) заощадженням коштів на редакторську підготовку; 2) намагання щонайшвидше отримати книгу, випустити її у друкарні, оминаючи видавництво; 3) стереотип, що автор людина грамотна, рукопис за ним можна не вичитувати або переглянути без особливого старання. (При цьому ігнорується обставина, що автор - спеціаліст у своїй галузі, але не фахівець книговидавничої справи. В Україні майже немає навчальних і довідкових видань для людей, які пишуть, на відміну, скажімо, від США, де щороку випускають десятки самовчителів, довідників, посібників для авторів різних рівнів кваліфікації та «письменницького» досвіду. В українських вищих начальних закладах ніколи не було спеціальних дисциплін на кшталт «Creative Writing» («творче писання», або писемна творчість), які б навчали створювати тексти різного функціонального призначення [7, С. 144, 210]).

Деякі автори, ігноруючи вимоги видавничого стандарту або зауваження редактора, закидають про абсурдність редакторської правки, не дозволяють редакторам удосконалювати тексти і змушують залишати у «сирому» вигляді (при цьому часто епатуючи лише формою, а не змістом). Літредактори тернопільського видавництва «Навчальна книга-Богдан» пишуть про конфлікт із популярною місцевою письменницею, яка висловила своє незадоволення щодо роботи редактора як такого: мовляв, ії̈ тексти настільки досконалі, що не потребують жодних редакторських правок [8]. Або у газеті «Хрещатик» 
опубліковано рецензію на книгу Д. Бондаренка «Красуні й бандити» (дніпропетровського видавництва «Дніпро-VAL»): головний з недоліків - брак редагування. Очевидно, принципова самостійність автора у виданні своїх творів дається взнаки: повість надруковано в авторській редакції. Деякі помилки помітить лише професійний редактор, але $є$ й такі, що побачиш і «неозброєним оком» [9]. Нищівно критикують авторську редакцію («авторська стилістика - не для людей зі слабкою нервовою системою») рецензенти на книгу М. Бриних «Шахмати» для дітей і дорослих»: «за сором'язливим зауваженням видавців «Текст подано в авторской редакции» приховується жорсткий суржик, який можуть витерпіти лише «крєпкі духом і сильні мазгамі» [10]; «Не даремно, потупивши погляд, видавщі змушені були поставити на книжці ремарку: «Текст подано в авторській редакції». Клянемося..., що з цих лінгвістичних чагарів не виплутатися жодному коректорові чи літредактору. Ба, й самому авторові» [11]. Висновок один: сором видавати літературу такого ґатунку.

Н. Зелінська висловлює думку про те (і з цим важко не погодитись), що фаховому редагуванню мусить підлягати будьякий текст, навіть якщо він належить найвідомішому авторові. Редагувати треба, незважаючи на звання, титули, імена і посади. Лише тоді ми досягнемо видавничої культури, якої так бракує сьогодні [6].

Компромісом називає стосунки «редактор-автор» 3 точки зору меж втручання редактора в авторський оригінал 3. Партико. Оскільки Україна належить до числа демократичних суспільств і на її території використовують плюралістичні теорії редагування, «межею втручання редактора в текст $€$ «мовчазний» компроміс, який виникає під час редагування між автором і редактором: редактор не може внести в текст жодного виправлення без згоди автора, проте може відмовити авторові в опублікуванні повідомлення». Інакше кажучи, межі втручання редактора в авторський текст це результат компромісу між тим, чи виправляти, і тим, чи публікувати [12, С. 143]. Літературний редактор видавництва «Навчальна книга-Богдан» підтверджує цю думку: «святе право будь-якого автора - відмовитися від співпраці з редактором, у таких випадках виходить виключно «в авторській редакції». Та, як на мене, допомога ще не зашкодила жодній книжці. Тому, щойно рукопис потрапляє до мене, я насамперед дізнаюся, на який рівень редакторського «втручання» погоджується автор. Нерідко трапляються такі тексти, які потрібно зовсім переписувати, інколи - тільки підкорегувати, виправити русизми, стилістику.... У кожної книги свій шлях» [8].

Авторові, безумовно, слід максимально «виписатися» під час підготовки, довести рукопис до узгодженої концепції. Часто зміст опрацювання тексту та більша частина його оформлення належать до категорії авторської роботи, що нерідко перекладається на редактора 
видавництва, який за автора «доводить» рукопис і фактично стає співавтором. Водночас бувають і випадки замовлень авторами написання книги редакторам, що нівелює як автора, так і редактора. Частина роботи, що пов'язана з оформленням і поліграфічними вимогами, попри авторську підготовленість, однак залишається атрибутом видавничої діяльності. Після редакторського опрацювання авторського оригіналу рукопису слід органічно вставити в нього підготовлений образотворчий матеріал, якщо він $€$, й оформити рукопис належним чином та передати його технічному редакторові. Після завершення цієї роботи авторський рукопис набуває статусу видавничого оригіналу. Проте процес роботи автора і редактора майбутнього видання на цьому не закінчується. Рукопис перетворюється на верстку, яку читають коректор, редактор, автор. Отже, автори потребують кваліфікованої редакторської підтримки.

Не варто забувати й про принципи редакційної етики: з повагою ставитися до автора і його праці, творчо підтримуючи його. Пам'ятати вже класичну фразу: не помилками автора, поміченими редактором, визначається якість авторського твору. Професійне редагування допомагає авторові замислитись над рукописом. Люди творчі - схильні до крайнощів. Хтось піддався на вмовляння близьких і схвильовано приніс свою роботу. Для нього почути компетентну думку - майбутня доля. Водночас професійне редагування позбавляє суспільство від графоманів та псев- донауковців. Підтвердженням цієї думки є, наприклад, рецензія О. В. Сарапіна на навчальний посібник Я. Я. Чорненького під назвою «Привид блукає в Україні, привид плагіату...», в якій автор після ретельного аналізу тексту видання стверджує, що автора книги варто називати «укладач», адже матеріал підручника не містить посилань на цитати, не вказує, що ці цитати - чужі думки, спотворює думки видатних науковців тощо. Звісно, пише рецензент, що можна послатися на прикру друкарську помилку, але на останній сторінці зазначено: «Книга друкується в авторській редакції» [13]. Чи стався б такий випадок, якби рукопис був опрацьований професійним редактором, фахівцем 3 конкретної тематики?! Редактор газети «Високий замок», письменниця Г. Вдовиченко вважає, що редактор - це особа, яка рятує автора від незручних ситуацій, які можуть виникнути через неточності у авторському оригіналі, що дуже часто відбувається з виданнями «в авторській редакції». Адже редактор поза надзвичайно важливою мовностилістичною правкою тексту виконує ще й колосальну фактологічну працю. Г. Вдовиченко належить до тих авторів, які виступають проти «авторської редакції», посилаючись на неспроможність автора здійснити об'єктивну самооцінку [14].

\section{Висновки}

Авторська редакція, зважаючи на окреслене коло проблем, потребує досконалого її вивчення та застосування на практиці. 
Вона має право на існування, хоча ставлення щодо її правомірності неоднозначне.

Вона дозволяє зекономити час та гроші і видавця, і автора. Серед негативних наслідків авторської редакції: неякісна продукція (мовностилістичні, фактич- ні, технічні помилки, плагіат тощо), позбавлення тексту оптимізації, применшення ролі редактора.

Авторські редакції творів минулих століть $€$ науково цікавими для істориків мови, літераторів, мовознавців та інших науковців.

\section{Список використаної літератури}

1. Різун В. В. Літературне редагування : підручник / В. В. Різун. - Київ : Либідь, 1996. - 240 с.

2. Галич В. М. Олесь Гончар - журналіст, публіцист, редактор : еволюція творчої майстерності : моногр. / В. М. Галич. - Київ : Наук. думка, 2004. $816 \mathrm{c}$.

3. Вимоги до оформлення статей із сайтів [Електронний ресурс]. - Pежим доступу : http://intelect-invest.org.ua; http://www:menr.gox.ua; http:// www.psyh.kiev.ua; http://www.doctos.com; radnuk.ihfo/index.php?start=49.

4. Лавриненко Н. А. Учебная книга в контексте гуманистически ориентированной образовательной парадигмы / Н. А. Лавриненко // Книжная культура : опыт прошлого и проблемы современности к 250-летию вузовского книгоиздания в России : Материалы междунар. науч. конф. (Москва, 20-21 сент. 2006 г.) / отв. ред. В. И. Васильев ; [сост. : Д. Н. Бакун, А. Ю. Самарин]. - Москва : Наука, 2006. - С. 179-181.

5. Тюрина Л. Г. Теоретическое обоснование вузовского ученика как педагогической системы / Л. Г. Тюрина // Проблемы полиграфии и издательского дела. - 2004. - № 3. - С. 94-96.

6. Бойко А. Альма-матер української книжки / А. Бойко // Дзеркало тижня / 24 листопада. - 2007. - № 45. [Електронний ресурс]. - Режим доступу : htpp ://www : dt.ua/newspaper/articles/51987\#.

7. Зелінська Н. В. Наукове книговидання в Україні : історія та сучасний стан : навч. посіб. для студ. вищ. навч. закл. / Н. В. Зелінська. - Львів : Світ, 2002. - 268 c. - ISBN 966-603-222-8.

8. Осадко Г. Та, що ілюструє пластиліном / Г. Осадко // Читомо. [Електронний ресурс]. - Режим доступу : http: //www : chytomo.com.

9. Зазвичай М. У супермаркетах завелися красуні й бандити / М. Зазвичай // Хрещатик. - 2008. - № 139(3356). - 7 серп. [Електронний ресурс]. Режим доступу : http: //www/kreschatik.kiev.ua/ru/3356/art/1218047941.html.

10. Гриценко Г. «Шахмати» для дітей і дорослих / Г. Гриценко. [Електронний ресурс]. - Режим доступу : http: //www.fact.ua/articles/article_212/.

11. Капуста В. Дитячий мат у дебюті дауна : навколо шахові й біля літературні екзерсиси в сучасному романі / В. Капуста // Українська літературна газета. - 2010. - № 5(11). - 5 берез. [Електронний ресурс]. Режим доступу : htpp://www.litgazeta.com.ua/node/493.

12. Партико 3. В. Загальне редагування : нормативні основи : навч. посіб. / З. В. Партико. - Львів : Афіша, 2001. - 516 с.

13. Сарапін О. В. Привид блукає в Україні, привид плагіату... / О. В. Сарапін // Українське релігієзнавство. - 2006. - № 39. - С. 154-161. [Електронний ресурс]. - Режим доступу : http://relifstudies.org.ua/main. ptp?display=element\&SID=8f08d41\& EID=21c5be6d\&page $=1$. 
14. Зустріч з Галиною Вдовиченко / Сайт Української академії друкарства. [Електронний ресурс]. - Режим доступу : http://www.uad.lviv.ua/index. ptp?option $=$ com content $\& \quad$ view $=$ article \&id $=\quad 114: 2010-10-17-10-05-$ 27\&catid=42catid=42: holovna\&1temid=1.

15. ДСТУ ГОСТ 7.1 : 2006. Бібліографічний запис. Бібліографічний опис. Загальні вимоги та правила складання (ГОСТ 7.1-2003, ІДТ). - [Чинний від 2007.07.01]. - Київ : Держспоживстандарт України, 2007. - 47 с. (Система стандартів з інформації, бібліотечної та видавничої справи).

16. Майсурадзе Ю. Ф. Энциклопедия книжного дела / Ю. Ф. Майсурадзе, А. М. Мильчин, Э. П. Гаврилов и др. - Москва : Юристь, 1998. - 536 с. - (Книжное дело). - ISBN 5-7975-0037-Х.

\section{References}

1. Rizun, V. V. (1996). Literaturne redahuvannia [Literary editing]. Kyiv: Lybid [in Ukrainian].

2. Halych, V. M. (2004). Oles Honchar - zhurnalist, publitsyst, redaktor: evoliutsiia tvorchoi maisternosti [Oles Honchar - journalist, publicist, editor: evolution of creative skill]. Kyiv: Nauk. dumka [in Ukrainian].

3. Vymohy do oformlennia statei iz saitiv [Requirements for registration of articles from sites]. Retrieved from http://intelect-invest.org.ua; http://www: menr.gox.ua; http://www.psyh.kiev.ua; http://www.doctos.com; radnuk.ihfo/ index.php?start $=49$ [in Ukrainian].

4. Lavrinenko, N. A. (2006 ). Uchebnaja kniga v kontekste gumanisticheski orientirovannoj obrazovatel'noj paradigmy [Educational book in the context of a humanistically oriented educational paradigm]. Journal of Knizhnaja kul'tura: opyt proshlogo i problemy sovremennosti $k$ 250-letiju vuzovskogo knigoizdanija $v$ Rossii - Book culture: the experience of the past and the problems of the present to the 250th anniversary of the university book publishing in Russia. Moscow: Nauka [in Russian].

5. Tjurina, L. G. (2004). Teoreticheskoe obosnovanie vuzovskogo uchenika kak pedagogicheskoj sistemy [Theoretical justification of the high school student as a pedagogical system]. Journal of Problemy poligrafii i izdatel'skogo dela - Problems of polygraphy and publishing, 3, 94-96 [in Russian].

6. Boiko, A. (2007). Alma-mater ukrainskoi knyzhky [Alma mater of the Ukrainian book]. Newspaper of Dzerkalo tyzhnia - Mirror of the week. November 24. Retrieved from htpp://www:dt.ua/newspaper/articles/51987\# [in Ukrainian].

7. Zelinska, N. V. (2002). Naukove knyhovydannia v Ukraini: istoriia ta suchasnyi stan [Scientific publishing in Ukraine: history and current state]. Lviv: Svit [in Ukrainian].

8. Osadko, H. Ta, shcho iliustruie plastylinom [The one that illustrates the plasticine]. Web-site of Chytomo. Retrieved from http: //www : chytomo.com [in Ukrainian].

9. Zazvychai, M. (2008). U supermarketakh zavelysia krasuni i bandyty [In supermarkets, beauties and gangsters were taken]. Newspaper of Khreshchatyk, 139(3356), 7 August. Retrieved from http: //www/kreschatik.kiev.ua/ru/ 3356/art/1218047941.html [in Ukrainian].

10. Hrytsenko, H. 'Shakhmaty' dlia ditei i doroslykh ['Chess' for children and adults]. Retrieved from http: //www.fact.ua/articles/article_212/ [in Ukrainian]. 
11. Kapusta, V. (2010). Dytiachyi mat u debiuti dauna: navkolo shakhovi i bilia literaturni ekzersysy $v$ suchasnomu romani [Children's mat in the debut of the dawn: around the chess and the literary ekzersis in the modern novel]. Newspaper of Ukrainska literaturna hazeta - Ukrainian Literary Newspaper, 5(11). 5 March. Retrieved from htpp://www.litgazeta.com.ua/node/493 [in Ukrainian].

12. Partyko, Z. V. (2001). Zahalne redahuvannia: normatyvni osnovy [General editing: normative bases]. Lviv: Afisha [in Ukrainian].

13. Sarapin, O. V. (2006). Pryvyd blukaie v Ukraini, pryvyd plahiatu... [Ghost wanders in Ukraine, ghost of plagiarism .... J. Journal of Ukrainske relihiieznavstvo - Ukrainian Religious Studies, 39, 154-161. Retrieved from http://relifstudies.org.ua/main.ptp?display=element\&SID=8f08d41\& EID=21c5be6d\&page $=1$ [in Ukrainian].

14. Zustrich z Halynoiu Vdovychenko [Meeting with Halyna Vdovychenko]. Sait Ukrainskoi akademii drukarstva - The site of the Ukrainian Academy of Printing. Retrieved from http://www.uad.Iviv.ua/index.ptp?option=com_content\& view $=$ article\&id $=114: 2010-10-17-10-05-27 \&$ catid $=42$ catid $=42$ : holovna\&1temid=1 [in Ukrainian].

15. National standards of Ukraine. (2007). DSTU HOST 7.1:2006. Biblio-hrafichnyi zapys. Bibliohrafichnyi opys. Zahalni vymohy ta pravyla skladannia [Bibliographic record. Bibliographic description. General requirements and rules of assembly]. Kyiv: Derzhspozhyvstandart Ukrainy [in Ukrainian].

16. Majsuradze, Ju. F. \& Mil'chin, A. M. \& Gavrilov, Je. P. \& others (1998). Jenciklopedija knizhnogo dela [Encyclopedia of book business]. Moscow: Jurist' [in Russian].

Предпринята попытка выделить и охарактеризовать основной круг проблемных вопросов, связанных с авторским редактированием. Обзор положительного и отрицательного опыта использования печатных материалов в авторской редакции.

Ключевые слова: задача редактора; авторское редактирование; качество публикаций; редакционноиздательский процесс, саморедактирование; авторское редактирование; литературный редактор; редакционная этика.

An attempt is made to isolate and characterize the main range of issues relating to the author's edition. Positive and negative experiences of the use of printed materials in author's edition was considered.

Keywords: editor task; author editing; quality of publications; editorial and publishing process; self-editing; author editing; literary editor; editorial ethics.

Рецензент - Т. Г. Файчук, к.філол.н., ст. науковий співробітник Інституту мовознавства ім. О. Потебні 